\title{
EVALUASI KANDUNGAN KLORIDA (CL-) dan DAYA HANTAR LISTRIK (DHL) AIR TANAH PADA SISTEM AKUIFER JAKARTA PERIODA 1990-2000
}

\author{
Oleh: \\ Robertus Haryoto Indriatmoko *) dan E. Myra. $\mathbf{J}^{* *}$ ) \\ *) Kelompok Teknologi Pengelolaan Air Bersih Dan Limbah Cair, Pusat Pengkajian Dan \\ PenerapanTeknologi Lingkungan, BPPT \\ **) Jurusan Teknologi Lingkungan Universitas Trisakti, Jakarta
}

\begin{abstract}
Evaluation of chloride (Cl-) content and electric conductivity (EC) of ground water in aquifer system is one method to identify salt water movement in aquifer system, which occurred as a result of changes in hydraulic equilibrium which cause by temporary variation of natural recharges and pumping of ground water at many layered aquifers.

Salt water movement in Jakarta aquifer system is evaluated based on mapping of chloride content at $500 \mathrm{mg} / \mathrm{L}$ and EC at $1500 \mu \mathrm{mhos} / \mathrm{cm}$ in many bored well during period of $1990-2000$. In the beginning chloride content and EC is in value only and with the addition of attribute data, namely coordinate, it could be used as input data. By using software namely SURF, the above input data is simulate to have a contour map of chloride and EC. Overlapping of the contour map to Jakarta base map will result in thematic map of chloride and EC distribution which represent salt water movement at Jakarta aquifer system.
\end{abstract}

Key word : Aquifers, Aquifer system, Chloride (Cl-), Electric Conductivity (EC), Map, Hydraulic Equilibrium, Ground water, SURF Software.

\section{PENDAHULUAN}

Air tanah pada sistem akuifer pantai Jakarta merupakan sumberdaya yang sangat penting yang dapat digunakan untuk berbagai keperluan antara lain: perkantoran, industri/jasa, fasilitas umum dan penduduk/domestik.

Air tanah pada sistem akuifer pantai tersebut dapat dijumpai pada 2 tipe sistem akuifer yaitu sistem akuifer tak tertekan (unconfined aquifer) dan sistem akuifer tertekan (Confine aquifer). Pada sistem tersebut aliran air tanah tawar dan aliran air tanah asin berada dalam suatu kesetimbangan hidrolis (steady state).

Kesetimbangan hidrosatis antara air tanah tawar dan air tanah asin dapat berubah oleh proses alam dan aktivitas manusia (misalnya oleh proses pengambilan secara berlebihan) Pengambilan air tanah secara berlebihan akan menyebabkan perubahan kemiringan lapisan antar muka (interface) yang cenderung semakin kearah darat.

Perubahan kemiringan lapisan antar muka yang semakin ke arah darat itu dapat terjadi pada sistem akuifer pantai Jakarta. Seperti telah diketahui bahwa sistem akuifer pantai Jakarta merupakan suatu sistem akuifer berlapis yang berbatasan dengan pantai. Adanya aktifitas berupa pengambilan air untuk berbagai keperluan akan memberikan perubahan berupa perubahan kemiringan atau pergeseran lapisan antar muka apakah akan semakin masuk ke lapisan akuifer air tanah tawar atau sebaliknya semakin kearah lapisan air tanah asin (laut).

Perubahan pergeseran lapisan itulah yang akan diamati dalam penelitian ini, dievaluasi melalui kandungan $\mathrm{CL}-$ dan $\mathrm{DHL}$ dari setiap data sumur bor. Data $\mathrm{Cl}$ - dan DHL dicoba untuk dievaluasi Dengan menggunakan data sekunder kualitas air tanah pada lapisan akuifer tertekan dan tak tertekan dari tahun ketahun maka dicoba untuk mengevaluasi dan memetakan distribusi parameter kimia air tanah (parametar $\mathrm{Cl}^{-}$dan DHL) pada sistem akuifer tersebut dari tahun 1990 sampai dengan tahun 2000.

\subsection{LATAR BELAKANG}

Saat ini jumlah penduduk di DKI Jakarta mencapai 10.421.948 Jiwa. Jumlah penduduk yang demikian besar ini tentu saja amat membutuhkan sumberdaya air yang mantap baik secara kualitas dan kuantitas.

Berdasarkan hasil perhitungan maka tingkat pemakaian air tanah saat ini adalah 22,054 L/dt atau 1,9 Juta $\mathrm{m} 3 /$ hari (Arie Herlambang dan R Haryoto I, 2003). Dasar perhitungannya adalah atas pemenuhan PDAM saat ini sebesar $15,430 \mathrm{~L} / \mathrm{dt}$. Air yang terjual 
$8,102 \mathrm{~L} / \mathrm{dt}$ dengan 663.000 satuan sambungan atau kurang lebih setara 4,5 juta orang. Jika diasumsikan kebutuhan air kota besar 250 It/Org/hari maka untuk Jakarta adalah 30,156 L/dt. Jika 15,430 L/dt air PDAM berasal dari air permukaan maka diperkirakan sisanya yaitu 22,054 L/dt atau 1,9 Juta m3/hari berasal dari air tanah.

Potensi air tanah menurut "Jakarta Water Resources Management System" (1994) adalah 28,196 L/dt terdiri dari 2,476 L/dt dari akuifer dalam dan 25,720 L/dt dari akuifer dangkal. Ini berarti bahwa potensi yang tersisa tinggal 6,141 L/dt. (21,7\%). Suatu jumlah yang patut menjadi perhatian kita semua.

Dalam suatu sistem akuifer pantai lapisan air tanah tawar dan air tanah asin dipisahkan oleh suatu lapisan antar muka ("interface") dalam suatu kesetimbangan ("steady state") secara hidrolis. Kesetimbangan lapisan antar muka dapat terganggu oleh proses pemompaan air tanah dan penambahan air tanah oleh proses imbuhan alami.

Untuk keperluan modeling biasanya orang akan memberikan suatu asumsi bahwa pada lapisan antar muka tersebut merupakan lapisan "imicible" (tidak bersatu). Dalam kenyataannya lapisan yang memisahkan air tanah tawar dan asin merupakan suatu zone transisi yang dibentuk oleh air itu sendiri yang memberikan efek yang disebabkan oleh proses difusi dan dispersi secara mekanis (Essaid, 1990).

Peningkatan jumlah pemakaian air tanah dalam sistem akuifer seperti di cekungan Jakarta yang berbatasan dengan laut akan mempengaruhi kesetimbangan kemiringan lapisan antar muka antara air asin dan air tawar dalam sistem akuifer. Pengambilan air tanah secara berlebihan dalam daerah ini akan mempengaruhi tingkat kemiringan lapisan antar muka yang semakin kearah darat. Adanya perubahan kemiringan lapisan antar muka ini akan terdeteksi melalui monitoring secara terus menerus terhadap air tanah dalam.

Parameter utama yang dapat digunakan untuk memonitor terjadinya pergeseran zone lapisan antar muka adalah Klorida ( $\mathrm{Cl}-$ ) dan Daya Hantar Listrik DHL.

Menurut Departemen Pemukiman dan Pengembangan Wilayah dalam buku Pedoman untuk Perencanaan Sumberdaya Air Wilayah Sungai, 2000, Klorida merupakan suatu parameter kimia yang ada dalam air dan membentuk perbedaan utama sistem ekologi (air tawar, air payau, dan air laut) Perubahan besar dalam lingkungan dapat terjadi ketika air tawar berubah menjadi air payau atau air asin atau kearah sebaliknya. Untuk itulah parameter klorida diperlukan dalam penilaian kualitas air. Perbedaan besar antara Klorida dengan substansi lain yang ada dalam sistem air adalah bukan proses yang terjadi yang didasarkan oleh Klorida. Dalam proses seperti sedimentasi, degradasi, generasi atau penmggumpalan tidak melibatkan Klorida. Satu-satunya proses yang mempengaruhi konsentrasi Klorida adalah pemindahan dan pencampuran. Klorida merupakan pelacak alami yang digunakan sebagai petunjuk dalam pelacak proses pencampuran dan pengangkutan. Tanpa ada pemahaman tentang proses pengangkutan dan pencampuran dari suatu sistem air maka evaluasi kualitas air tidak dapat dilaksanakan.

Hampir semua batas konsentrasi mempunyai konsentrasi spesifik kloridanya sendiri. Analisis berdasarkan pola-pola konsentrasi klorida sering dapat dipahami secara cepat sumbermana yang bergerak dari suatu tempat ketempat lain. Klorida juga penting khususnya ketika model kualitas air dilaksanakan untuk mengevaluasi sistem air. Komponen utama dalam model kualitas air adalah komponen pengangkutan dan pencampuran.

Daya hantar listrik merupakan parameter yang menunjukkan kandungan ion dalam air sehingga suatu larutan mudah atau sukar dalam menghantarkan listrik. DHL bukan merupakan parameter yang relevan untuk mengukur polusi, akan tetapi dapat digunakan sebagai paramenter untuk mengetahui tingkat kegaraman dalam air.

\subsection{TUJUAN dan SASARAN}

Tujuan dilakukannya penelitian ini adalah melakukan evaluasi/penilaian pergerakan air tanah asin dalam sistem akuifer pantai dengan melakukan pengamatan terhadap kandungan $\mathrm{Cl}$ pada konsentrasi $500 \mathrm{mg} / \mathrm{l}$ dan $\mathrm{DHL}$ pada nilai konduktifitas $1500 \mu \mathrm{mhos} / \mathrm{cm}$ air tanah pada lapisan akuifer tak tertekan $<40 \mathrm{~m}$ dan dan akuifer tertekan $>40 \mathrm{~m}$ periode $1990-2000$

Sasaran penelitian adalah sebagai berikut

1. Membuat peta konturing konsentrasi CLdan DHL dalam air tanah dari tahun 1990 sampai 2000

2. Menganalisa pola dan arah perubahan konsentrasi $\mathrm{Cl}$ - dan $\mathrm{DHL}$ dalam air tanah dari tahun 1990 sampai 2000.

\subsection{METODOLOGI}

Langkah untuk mencapai tujuan penelitian dilakukan dengan cara sebagai berikut:

1. Kompilasi data sekunder kualitas air tanah dari berbagai sumur bor dari tahun 1990 sampai tahun 2000.

2. Tabulasi data kualitas air dalam hal ini $\mathrm{Cl}$ dan DHL dari setiap sumur bor dan pemberian atribut koordinat UTM . 
3. Kedudukan elevasi air tanah dikelompokkan menjadi 2 (dua) yaitu: 1 . Elevasi air tanah < $40 \mathrm{~m}$ (akuifer tak tertekan) dan 2. Elevasi air tanah $>40 \mathrm{~m}$ (akuifer tertekan).

4. Proses konturing dilakukan dengan terlebih dahulu menyiapkan input yang terdiri dari Kolom $X$ (untuk absis), kolom $Y$ (untuk Ordinat) dan Kolom Z untuk Cl- atau DHL. Masing-masing dikelompokkan menurut tahun ke tahun dengan menggunakan software yang disebut "Surf"

5. Proses tumpang tindih antara peta konturing dan peta dasar Cekungan Jakarta pada koordinat yang sama.

6. Pemetaan kembali dengan peta hasil tumpang tindih untuk deliniasi batas yang diinginkan.

\section{KONDISI FISIK DAERAH KAJIAN}

Jakarta mempunyai luas kurang lebih 66.164,15 Ha dengan jumlah penduduk sebanyak 8,3 Juta orang, dengan kepadatan 126 orang/Ha

Komposisi penggunaan lahan di Jakarta terdiri dari penggunaan lahan untuk pemukiman $43.230,00 \mathrm{Ha}(65,4 \%)$, Industri $3.970,00 \mathrm{Ha}(6$ $\%)$, Perkantoran dan Pergudangan 6.955,00 $\mathrm{Ha}$ (10,5\%), Taman 1.328,00 (2\%) dan Lainnya 10.669.00 Ha (16,1\%).

Menurut DGTL dan PAM Jaya, 1991 dalam laporan mengenai Penyelidikan Zona Air Asin di Wilayah DKI Jakarta, rencana pengembangan sampai dengan tahun 2205 , pengembangan pembangunan akan diarahkan ke bagian Barat, Pusat dan Timur, meliputi wilayah Cengkareng, Kota, Sunter, Tanjungpriok dan Pulogadung. Daerah tersebut akan dikembangkan sebagai daerah bagi kawasan industri, dan pusat perdagangan.

Daerah wilayah Tenggara, Selatan, Barat Daya, Sebagian wilayah Barat Laut, dan Timur Laut termasuk wilayah Halim dan Cilandak akan dipertahankan sebagai daerah jalur hijau, dan daerah pertanian (daerah konsumsi air sedikit, daerah resapan )

Wilayah yang menjadi daerah kajian secara geografis terletak pada koordinat UTM 683500 sampai 719400 dan 9300000 sampai 9325750. Secara administrasi meliputi wilayah utara dari Cengkareng (Tangerang) sampai Marunda dan wilayah selatan dari Cilandak sampai Pondok Gede.

\subsection{GEOLOGI/GEOMORFOLOGI}

Geologi permukaan daerah Jakarta dan sekitarnya dibagi menjadi 6 sistem yaitu: 1. Formasi Jatiluhur (Miosen). 2. Formasi
Bojongmanik (Miosen).3. Formasi Genteng (Pliosen). 4. Formasi Vulkanik Tua (Pleistosen). 5. Formasi Vulkanik Muda (Pleistosen). 6. Sedimen Aluvial

Formasi Jatiluhur (Miosen) dapat dilihat di pegunungan sebelah tenggara cekungan Jakarta, litologi formasi ini tersusun oleh batu lempung berlapis, pasir kuarsa, dan napal. Formasi ini mengalami pemadatan sehingga bersifat sebagai batuan dasar yang impermeabel. Formasi Bojongmanik (Miosen) mempunyai tiga anggota, angota yang paling bawak susunan utama adalah batu gamping dengan selang-seling antara lempung dan pasir. Batuan umumnya keras dengan permeabilitas rendah, tetapi mengandung retakan dan lubang hasil pelarutan (solusi). Anggota kedua terdiri dari lempung, batu pasir kuarsa, batu tuf dengan kandungan fosil muluska. Batuan ini bersifat impermeabel. Anggota ke tiga terdiri dari batu pasir, yang mengandung lempung, batu pasir tuf kasar, dengan selang seling batu gamping. Batuan ini umumnya mempunyai permeabilitas rendah.

Formasi Genteng (Pliosen) Letaknya di daerah Tangerang, sekaligus merupakan bagian dasar sungai Cisadane. Bagian atas formasi ini membentuk akuifer di daerah Tangerang. Formasi ini tersusun oleh batu pasir kasar tufaan, lempung, gabungan fragmen pumis.

Formasi Vulkanik Tua, Fornasi ini terbagi kedalam 4 anggota yaitu Breksi lahar (Vb), Aliran Lava Vulkanik Tua (VE), batuan Vulkanik Tua Terpropilitisasi (Vp) dan Vulkanik Tua yang sulit dibedakan $(\mathrm{Vu})$. Penyebaran formasi ini sangat luas di daerah selatan, pegunungan barat dan timur. Sifat batuan permeabilitas tinggi sampai rendah.

Formasi Vulkanik muda, formasi ini dikelompokkan menjadi vulkanik muda (V1), batuan vulkanik mengandung pumis ( $\mathrm{Va}$ ) dan batuan vulkanik muda (V), Batuan yang paling atas (V) terdistribusi luas dan terdiri dari lempung tufaan, pasir, konglomerat, endapan lahar, lapuk. Lapisan ini mempunyai permeabilitas tinggi dan membentuk akuifer tak tertekan.

Sedimen aluvial, sedimen aluvial di Jakarta dibagi menjadi 3 (tiga) yaitu: aluvium sungai daerah pantai (As), pematang pantai (Ap) dan aluvium (A1), As merupakan endapan sungai tua (purba) yang tersebar sepanjang pantai.

\subsection{IKLIM}

Tipe iklim di daerah kajian secara umum adalah iklim tropis. Musim hujan berada dalam perioda Nopember sampai Mei, sedangkan musim kemarau pada Juni sampai Oktober. Hujan di daerah pantai lebih kecil dibanding dengan di daerah pegunungan. Curah hujan 
tahunan berkisar antara 2000-4000 mm. Temperatur udara berkisar antara 250-27 ० C, kelembaban relatif berkisar antara 70\%-90\%.

\subsection{SISTEM AKUIFER}

Menurut Soekardi (1982) satuan hidrogeologi Jakarta dibagi menjadi 2 lapisan yaitu akuifer tak tertekan dan tertekan. Lapisan akuifer tak tertekan memiliki kedalaman sampai $60 \mathrm{~m}$. Lapisan ini dikelompokkan kedalam unit stratigrafi I. Lapisan ini disusun oleh litologi yang terdiri dari lempung, lempung berpasir, lempung pasir tufaan, pasir berlempung, pasir dan gravel.

Lapisan akuifer tertekan dikelompokkan menjadi 3 (tiga) grup. Pada grup I (A, B) terdiri dari lapisan akuitard I, Artetis, Akuifer artetis I dan Akuitard II. Lapisan akuifer pada grup I ini meliputi 4 (empat) satuan stratigrafi yaitu Unit II(4-12 M), III(3-65 M), IV(35-60 M) dan V(4-18 M). Lapisan akuifer grup I unit II dan III ini mempunyai Litologi yang terdiri dari Lempung keras, lempung berpasir, pasir, grafel batu pasir, dan konglomerat. Unit IV dan V mempunyai litologi lempung, lempung berpasir, pasir kuarsa dan lempung keras. Lapisan akuifer grup I ini diapit oleh dua buah lapisan semi permeabel mempunyai kedalaman sampai $150 \mathrm{~m}$.

Lapisan akuifer grup II C merupakan lapisan akuifer artetis II, lapisan ini termasuk dalam unit stratigrafi $\mathrm{VI}(25-100 \mathrm{M})$, $\mathrm{VII}(40-60 \mathrm{M})$, dan VIII (30-50 M) dengan litologi terdiri dari: lempung berpasir, pasir berlempung dengan pasir kuarsa, pasir kuarsa gravel, lempung dan lempung berpasir. Lapisan akuifer grup II C ini juga diapit oleh lapisan semi permeabel dengan kedalaman sampai $250 \mathrm{~m}$.

Lapisan akuifer grup III D terdiri dari lapisan Akuitard III dan akuifer artetis III. Lapisan grup III $D$ ini termasuk dalam untit stratigrafi IX(?M), $\mathrm{X}($ ?M) dan $\mathrm{XI}($ ?M) dengan litologi yang terdiri dari lempung, lempung berpasir, batu gampinglempung pasiran, lempung napal dan batu pasirkuarsa dan batuan dasar impermeabel.

\subsection{AIR TANAH}

Air tanah pada sistem akuifer cekungan Jakarta terkait erat dengan siklus air. Hujan yang terjadi memberikan kontribusi yang besar pada jumlah air tanah. Berbagai data menunjukkan adanya kaitan yang langsung antara jumlah hujan dan pengaruhnya terhadap fluktuasi air tanah air tanah.

Fluktuasi air tanah antara perioda September 1993-1994 rata-rata mengalami penurunan 0,84 M/Tahun. Di sekitar Cilandak bahkan mencapai 2,64 M/Tahun. Total pengambilan air tanah pada tahun 1994 mencapai 33,80 Juta M3.
Berdasarkan pengamatan terhadap fluktuasi air tanah sampai perioda September 1995 terdapat beberapa lokasi yang kedudukan muka air tanah ada dibawah muka air laut, yaitu: 1. Wilayah Kapuk, Muara Angke, Tambora, Tamansari, Grogol, dan sekitar Gambir berkisar antara 0,27-2,5 M dibawah muka air laut (dbml). 2. Wilayah Koja, Pulo Gadung, Cakung berkisar antara 0,10-4,35 M dbml.

Tabel 1. Jumlah Sumur Bor danPengambilan Air Tanah.

\begin{tabular}{|c|r|r|}
\hline TAHUN & JML SUMUR & $\begin{array}{l}\text { PENGAMBILAN } \\
\text { DLM JUTA M3 }\end{array}$ \\
\hline 1990 & 2600 & 28 \\
\hline 1991 & 2640 & 31 \\
\hline 1992 & 2700 & 31,75 \\
\hline 1993 & 2800 & 32,60 \\
\hline 1994 & 3016 & 33,80 \\
\hline 1995 & 3200 & 32,20 \\
\hline 1996 & 3400 & 27 \\
\hline 1997 & 3500 & 22,60 \\
\hline 1998 & 3600 & 16,80 \\
\hline 1999 & 3117 & 16,40 \\
\hline 2000 & 3224 & 17,50 \\
\hline
\end{tabular}

Sumber: Konservasi Air Tanah Derah Jakarta dan sekitarnya, DGTL 2000

Terjadinya penurunan muka air tanah juga terjadi pada lapisan akuifer tertekan (lapisan II). Pada perioda Agustus sampai September 1995 diperoleh gambaran sebagai berikut: 1 . Wilayah barat meliputi Cengkareng, Pedongkelan, Porisgaga, Kapuk dan Muara Angke posisi muka air tanah berkisar antara 27-52,98 m dbml. 2 . Wilayah utara meliputi Tanjung Priok, Cilincing, Walangbaru, Sunter, Kelapa Gading dan Cempaka Putih kedudukan muka air berkisar antara 23,1-32,82 m dbml. 3. Wilayah timur meliputi Tambun, Rawa Rengas, Kaliabang, Teluk Pucung dan Cakung kedudukan muka air tanah berkisar antara 12,7-42,4 M dbml. 4. Wilayah selatan meliputi Slipi, Senayan dan Pancoran kedudukan muka air tanah berkisar antara 8,49-13,4 M dbml.

Penurunan muka air tanah pada periode Agustus-September 1995 juga terjadi pada lapisan akuifer III. Lokasi yang dapat dijumpai adalah: 1. Wilayah barat meliputi Porisgaga, Cengkareng, Pedongkelan dan Kapuk, kedudukan muka air tanah berkisar antara 26,1746,7 M dbml. 2. Wilayah timur meliputi daerah Walang dan Sunter, kedudukan muka air tanah mencapai 33,77 M dmal.

Dikawatirkan adanya penurunan muka air tanah tersebut dapat mempengaruhi kualitas air tanah berupa peningkatan salinitas air tanah oleh air asin. Tingkat salinitas air dapat ditinjau dari 
tiga parameter utama yaitu 1. Zat Padat Terlarut (TDS). 2. Daya Hantar Listrik (DHL) dan 3. Kadar Clor (Cl-). Adapun klasifikasinya dapat dilihat pada Tabel 2.

Tabel 2 : Klasifikasi Tingkat Salinitas Air Tanah

\begin{tabular}{|l|c|c|c|}
\hline $\begin{array}{c}\text { SIFAT } \\
\text { AIR }\end{array}$ & TDS $(\mathrm{mg} / \mathrm{L})$ & $\begin{array}{c}\text { DHL } \\
\mu \mathrm{mhos} / \mathrm{cm}\end{array}$ & $\begin{array}{c}\text { Cl- } \\
\mathrm{Mg} / \mathrm{L}\end{array}$ \\
\hline Tawar & $<1000$ & $<1500$ & $<500$ \\
\hline Agak & $1000-3000$ & $1500-$ & $500-2000$ \\
Payau & $3000-$ & 5000 & $2000-$ \\
\hline Payau & 10000 & 15000 & 5000 \\
\hline Asin & $10000-$ & $15000-$ & $5000-$ \\
& 35000 & 50000 & 19000 \\
\hline Laut & $>35000$ & $>50000$ & $>19000$ \\
\hline
\end{tabular}

Sumber: DGTL dan PAM Jaya, 1991

\section{HASIL DAN PEMBAHASAN}

Seperti diketahui bahwa sistem akuifer pada cekungan Jakarta merupakan sistem akuifer berlapis yang terdiri dari sistem akuifer tak tertekan dan tertekan. Berdasarkan data geologi diperoleh gambaran bahwa sistem lapisan akuifer tertekan dipisahkan oleh lapisan akuitard yang berlensa-lensa yang tidak seidial dalam teori. Tidak dipungkiri bahwa terjadi kebocoran akuifer antar lapisan hal ini memungkinkan terjadinya aliran antar lapisan baik aliran kebawah maupun keatas. Adanya kebocoran antar lapisan ini sangat dikawatirkan dapat mempengaruhi kualitas air atau parameter yang dievaluasi.

Faktor lain yang dapat berpengaruh terhadap hasil analisis adalah tidak ada petunjuk yang jelas terhadap kualitas sumur. Apakan desain sumur monitor benar-benar dapat menggambarkan kualitas air pada satu lapisan akuifer atau tidak.

Hasil evaluasi dikelompokkan menjadi dua yaitu evaluasi untuk lapisan akuifer tak tertekan dan evaluasi untuk sistem akuifer tertekan. Pengelompokan ini merupakan konsekuensi logis dari perkiraan adanya hasil evaluasi dari sistem akuifer tertekan dimana sangat sukar menggambarkan kualitas air pada lapisan akuifer yang diukur. Berdasarkan pada pertimbangan tersebut maka hasil analisis dapat dijelaskan sebagai berikut:

\subsection{ANALISIS KONSENTRASI CL DAN DHL DALAM SISTEM AKUIFER TAK TERTEKAN}

Berdasarkan data kualitas air tanah untuk kandungan CL- diatas $500 \mathrm{mg} / \mathrm{l}$ dan $\mathrm{DHL}>1500$ $\mu$ mhos hasil pengukuran tahun 1990 , setidaknya terdapat 3 (tiga) lokasi utama yaitu wilayah
Kecamatan Penjaringan, Sawah Besar dan Cengkareng. Data hasil pengukuran langsung menunjukkan bahwa konsentrasi klorida di Kecamatan Penjaringan mempunyai kisaran antara 500-1500 mg/l, Sawah Besar mempunyai kisaran antara 500-2250 mg/l, sedangkan Cengkareng antara $500-3250 \mathrm{mg} / \mathrm{l}$. Wilayah dengan konsentrasi $\mathrm{Cl}$ > $500 \mathrm{mg} / \mathrm{l}$ dan $\mathrm{DHL}>$ $1500 \mu$ mhos umumnya berada di wilayah Jakarta Barat dan Utara. Pada periode 1990 jumlah pengambilan air tanah melalui sumur bor mencapai 28 juta m3.

Berdasarkan data kualitas air tanah untuk hasil pengukuran tahun 1991, wilayah yang mempunyai parameter CL- diatas $500 \mathrm{mg} / \mathrm{l}$ adalah: 1. Wilayah Pademangan dengan konsentrasi 500-1750 mg/l, 2. Wilayah Penjaringan antara 500-1750 mg/l, 3. Wilayah Cengkareng antara 500-1250 mg/l, 4. Wilayah Kelapa Gading 500-750 mg/l. Wilayah dengan konsentrasi $\mathrm{Cl}->500 \mathrm{mg} / \mathrm{l}$ dan $\mathrm{DHL}>1500$ umhos umumnya berada di wilayah Jakarta Barat dan Utara. Periode 1991 jumlah pengambilan air tanah melalui sumur bor mencapai 31 juta m3.

Berdasarkan data kualitas air tanah untuk hasil pengukuran tahun 1992, wilayah yang mempunyai parameter CL- diatas $500 \mathrm{mg} / \mathrm{l}$ adalah: 1. Wilayah Penjaringan dengan konsentrasi 500-1750 mg/l, 2. Pademangan dan Tanjung Priok antara 500-3000 mg/l, 3 . Cengkareng antara 500-2000 mg/l, 4. Wilayah Kalideres antara 500-1000 mg/l. Wilayah dengan konsentrasi $\mathrm{Cl}->500 \mathrm{mg} / \mathrm{l}$ dan $\mathrm{DHL}>1500$ umhos umumnya berada di wilayah Jakarta Barat dan Utara. Pada periode 1992 jumlah pengambilan air tanah melalui sumur bor mencapai 31,75 juta m3.

Berdasarkan data kualitas air tanah untuk hasil pengukuran tahun 1993, wilayah yang mempunyai parameter CL- diatas $500 \mathrm{mg} / \mathrm{l}$ adalah: 1. Wilayah Pademangan dan Tanjung Priok mempunyai konsentrasi $\mathrm{Cl}$ - antara 500$1250 \mathrm{mg} / \mathrm{l}$., 2. Wilayah Cengkareng antara 5002000 mg/l., 3. Kecamatan Kalideres antara 500$1000 \mathrm{mg} / \mathrm{l}$. Wilayah dengan konsentrasi $\mathrm{Cl}->500$ $\mathrm{mg} / \mathrm{l}$ dan $\mathrm{DHL}>1500$ umhos umumnya berada di wilayah Jakarta Barat dan Utara. Pada periode 1993 jumlah pengambilan air tanah melalui sumur bor mencapai 32,6 juta m3.

Berdasarkan data kualitas air tanah untuk hasil pengukuran tahun 1994, wilayah yang mempunyai parameter CL- diatas $500 \mathrm{mg} / \mathrm{l}$ adalah: 1. Wilayah Penjaringan mempunyai konsentrasi Cl- antara 500-2000 mg/l., 2.Cilincing, Cakung dan Cengkareng antara 500$1250 \mathrm{mg} / \mathrm{l}$., 3. Tanjung Priok dan Pademangan antara 500-1000 $\mathrm{mg} / \mathrm{l}$. Wilayah dengan konsentrasi $\mathrm{Cl}->500 \mathrm{mg} / \mathrm{l}$ dan $\mathrm{DHL}>1500$ $\mu$ mhos umumnya berada di wilayah Jakarta 
Barat, Utara dan Timur. Pada periode 1994 jumlah pengambilan air tanah melalui sumur bor mencapai 33,8 juta m3.

Berdasarkan data kualitas air tanah untuk hasil pengukuran tahun 1995, wilayah yang mempunyai parameter CL- diatas $500 \mathrm{mg} / \mathrm{l}$ adalah: 1. Wilayah Penjaringan dengan konsentrasi antara 500-1750 mg/l., 2. Kecamatan Tanjung Priok, Pademangan dan Sawah Besar antara 500-1500 mg/l., 3. Wilayah Cilincing dan Cakung antara 500-1000 mg/l. Wilayah dengan konsentrasi $\mathrm{Cl}$ > $500 \mathrm{mg} / \mathrm{l}$ dan $\mathrm{DHL}>1500$ umhos umumnya berada di wilayah Jakarta Barat, Utara dan Timur. Pada periode 1995 jumlah pengambilan air tanah melalui sumur bor mencapai 32,20 juta m3.

Berdasarkan data kualitas air tanah untuk hasil pengukuran tahun 1996, wilayah yang mempunyai parameter CL- diatas $500 \mathrm{mg} / \mathrm{l}$ adalah: 1. Wilayah Cilincing dengan konsentrasi antara 500-1500 mg/l., 2. Cengkareng antara 500-2000 mg/l., 3. Penjaringan dan Tanjung Priok antara 500-1000 mg/l. Wilayah dengan konsentrasi $\mathrm{Cl}->500 \mathrm{mg} / \mathrm{l}$ dan $\mathrm{DHL}>1500$ umhos umumnya berada di wilayah Jakarta Barat dan Utara. Pada periode 1996 jumlah pengambilan air tanah melalui sumur bor mencapai 27 juta m3.

Berdasarkan data kualitas air tanah untuk hasil pengukuran tahun 1997, wilayah yang mempunyai parameter CL- diatas $500 \mathrm{mg} / \mathrm{l}$ adalah: 1. Wilayah Penjaringan dengan konsentasi antara 500-1750 mg/l. 2. Kalideres antara 500-750 mg/l., 3. Tanjung Priok dan Pademangan antara 500-1500 mg/l., 4. Cilincing dan Cakung antara 500-1000 mg/l. Wilayah dengan konsentrasi $\mathrm{Cl}->500 \mathrm{mg} / \mathrm{l}$ dan $\mathrm{DHL}>$ $1500 \mu$ mhos umumnya berada di wilayah Jakarta Barat dan Utara. Pada periode 1997 jumlah pengambilan air tanah melalui sumur bor mencapai 22,6 juta m3.

Berdasarkan data kualitas air tanah untuk hasil pengukuran tahun 1998, wilayah yang mempunyai parameter CL- diatas $500 \mathrm{mg} / \mathrm{l}$ adalah: 1. Wilayah Penjaringan dengan konsentrasi antara lain 500-2250 mg/l. 2 . Cengkareng antara 500-2000 mg/l., 3. Koja dan Kelapa Gading antara 500-750 mg/l., 4. Tamansari, Tambora dan Cilincing antara 500$1000 \mathrm{mg} / \mathrm{l}$. Wilayah dengan konsentrasi $\mathrm{Cl}->500$ $\mathrm{mg} / \mathrm{l}$ dan $\mathrm{DHL}>1500$ umhos umumnya berada di wilayah Jakarta Barat, Utara dan Timur. Pada periode 1998 jumlah pengambilan air tanah melalui sumur bor mencapai 16,8 juta m3.

Berdasarkan data kualitas air tanah untuk hasil pengukuran tahun 1999, wilayah yang mempunyai parameter CL- diatas $500 \mathrm{mg} / \mathrm{l}$ adalah: 1. Wilayah Grogol dengan konsentrasi antara 500-1500 mg/l. 2. Kemayoran antara 500650 mg/l. 3. Pademangan, Cakung, Cilincing antara 500-1000 mg/l 4. Kalideres dan Penjaringan antara $500-1250 \mathrm{mg} / \mathrm{l}$. Wilayah dengan konsentrasi $\mathrm{Cl}$ - $>500 \mathrm{mg} / \mathrm{l}$ dan $\mathrm{DHL}>$ 1500 umhos umumnya berada di wilayah Jakarta Barat, Utara dan Timur. Pada periode 1999 jumlah pengambilan air tanah melalui sumur bor mencapai 16,40 juta m3.

Berdasarkan data kualitas air tanah untuk hasil pengukuran tahun 2000, wilayah yang mempunyai parameter CL- diatas $500 \mathrm{mg} / \mathrm{l}$ adalah: 1. Wilayah Cengkareng dengan konsentrasi antara 500-1000 mg/l. 2. Penjaringan, Pademangan dan Cakung antara 500-750 mg/l. Wilayah dengan konsentrasi $\mathrm{Cl}->$ $500 \mathrm{mg} / \mathrm{l}$ dan $\mathrm{DHL}>1500 \mu$ mhos umumnya berada di wilayah Jakarta Barat, Utara dan Timur. Pada periode 2000 jumlah pengambilan air tanah melalui sumur bor mencapai 17,5 juta m3.

Berdasarkan hasil analisis selama perioda 1990-2000 untuk sistem akuifer tak tertekan diperoleh gambaran bahwa terdapat kaitan yang nyata antara terjadinya pergerakan air tanah asin dengan besarnya jumlah pengambilan air tanah melalui sumur bor.

\subsection{ANALISIS KONSENTRASI CL DAN DHL DALAM SISTEM AKUIFER TERTEKAN}

Berdasarkan data kualitas air tanah untuk hasil pengukuran tahun 1990, wilayah yang mempunyai parameter $\mathrm{CL}$ - diatas $500 \mathrm{mg} / \mathrm{l}$ dan DHL $>1500 \mu$ mhos adalah: Wilayah Kecamatan Kalideres dan Penjaringan dengan konsentrasi antara 500-750 mg/l, merupakan wilayah di Jakarta Barat dan Utara.

Berdasarkan data kualitas air tanah untuk hasil pengukuran tahun 1991, diperoleh gambaran bahwa tidak terdapat wilayah yang mempunyai parameter CL- diatas $500 \mathrm{mg} / \mathrm{l}$ dan DHL > 1500 umhos.

Berdasarkan data kualitas air tanah untuk hasil pengukuran tahun 1992, wilayah yang mempunyai parameter CL- diatas $500 \mathrm{mg} / \mathrm{l}$ dan DHL > $1500 \mu$ mhos adalah: Wilayah Kalideres dengan konsentrasi antara 500-2000 mg/l

Berdasarkan data kualitas air tanah untuk hasil pengukuran tahun 1993, wilayah yang mempunyai parameter $\mathrm{CL}$ - diatas $500 \mathrm{mg} / \mathrm{l}$ dan DHL > $1500 \mu$ mhos adalah: Wilayah Kalideres dengan konsentrasi antara 500-1500 mg/l

Berdasarkan data kualitas air tanah untuk hasil pengukuran tahun 1994, wilayah yang mempunyai parameter CL- diatas $500 \mathrm{mg} / \mathrm{l}$ dan DHL > $1500 \mu$ mhos adalah: masih merupakan wilayah Kalideres dengan konsentrasi antara 500-1500 mg/l. Merupakan wilayah di Jakarta Barat

Berdasarkan data kualitas air tanah untuk hasil pengukuran tahun 1995, tidak terdapat 
wilayah yang mempunyai air tanah dengan kandungan parameter CL- diatas 500 mg/l dan DHL > $1500 \mu$ mhos.

Berdasarkan data kualitas air tanah untuk hasil pengukuran tahun 1996, wilayah yang mempunyai parameter CL- diatas $500 \mathrm{mg} / \mathrm{l}$ dan DHL > 1500 umhos adalah: Wilayah Kalideres Jakarta Barat dengan konsentrasi antara 500$750 \mathrm{mg} / \mathrm{l}$.

Berdasarkan data kualitas air tanah untuk hasil pengukuran tahun 1997, wilayah yang mempunyai parameter CL- diatas $500 \mathrm{mg} / \mathrm{l}$ dan DHL > 1500 umhos adalah: Wilayah Tambora Jakarta Barat dengan konsentrasi antara 500$750 \mathrm{mg} / \mathrm{l}$.

Berdasarkan data kualitas air tanah untuk hasil pengukuran tahun 1998, wilayah yang mempunyai parameter CL- diatas $500 \mathrm{mg} / \mathrm{l}$ dan DHL > $1500 \mu$ mhos adalah: Wilayah Tambora Jakarta Barat dengan konsentrasi antara 500$1500 \mathrm{mg} / \mathrm{l}$.

Berdasarkan data kualitas air tanah untuk hasil pengukuran tahun 1999, wilayah yang mempunyai parameter CL- diatas $500 \mathrm{mg} / \mathrm{l}$ dan DHL > $1500 \mu$ mhos adalah: Wilayah Tambora Jakarta Barat dengan konsentrasi 500-1250 mg/l.

Berdasarkan data kualitas air tanah untuk hasil pengukuran tahun 2000, wilayah yang mempunyai parameter CL- diatas $500 \mathrm{mg} / \mathrm{l}$ dan DHL > $1500 \mu$ mhos adalah: Wilayah Tambora dan Kalideres dengan konsentrasi antara 500$1250 \mathrm{mg} / \mathrm{l}$.

Berdasarkan hasil analisis selama perioda 1990-2000 untuk sistem akuifer tertekan maka pergerakan air asin hanya berkisar diwilayah Jakarta Barat.

\section{KESIMPULAN}

Beberapa kesimpulan yang dapat diambil dari kegiatan ini adalah sebagai berikut :

- Terdapat kaitan yang nyata antara peningkatan jumlah pengambilan air tanah dengan pergerakan air tanah asin dalam sistem akuifer air tanah Jakarta

- Pergerakan air tanah asin dalam sistem akuifer lapisan tak tertekan menempati daerah yang lebih luas jika dibanding dengan sistem akuifer tertekan. Wilayah penyebaran pada sistem akuifer tak tertekan meliputi Wilayah Jakarta Barat, Utara dan Timur sedangkan untuk sistem akuifer tertekan hanya berkisar wilayah Jakarta Barat dan Utara.

\section{DAFTAR PUSTAKA}

1. Arie Herlambang dan Robertus Haryoto I, 2003, Pada Seminar Peran hasil Litbang Teknologi Lingkungan Dalam Menunjang Pembangunan Berwawasan Lingkungan, BPPT. Jakarta

2. Bambang W. 1990. "Salt Water Intrusion in Jakarta Groundwater Basin". Dinas Pekerjaan Umum. Jakarta.

3. Departemen Pemukiman dan Pengembangan Wilayah Direktorat Jenderal Penataan Ruang dan Pengembangan Wilayah dan Asosiasinya, 2000, Pedoman Untuk Perencanaan Sumberdaya Air Wilayah Sungai, Bagian 6 Kualitas Air, DPPW. Jakarta

4. Direktorat Geologi Tata Lingkungan dan PAM Jaya, 1991. Penyelidikan Zona Air Asin di Wilayah DKI Jakarta. DGTL. Bandung

5. Direktorat Geologi tata Lingkungan. 1991. Laporan Hidrologi dan Konservasi Air Tanah di Wilayah DKI Jakarta dan Sekitarnya. DGTL Bandung.

6. Direktorat Geologi Tata Lingkungan. 2000. Konservasi Air Tanah Jakarta dan Sekitarnya. DGTL Bandung.

7. Essaid, H.I. 1990. The Computer Model Sharp, A Quasi Three Dimensional Finite Difference Model to Simulate Freshwater and Saltwater Flow in Layered Coastal Aquifer Systems, USGS, California.

8. JICA, 1990, Laporan: "The Studi on Urban Drainage Wastewater Disposal Project in The City of Jakarta", JICA-RI.

9. The Institution of Engineers, Australia, 1987, "Australian Rainfall and Runoff" $A$ Guide to Flood Estimation, IEA. Australia. 


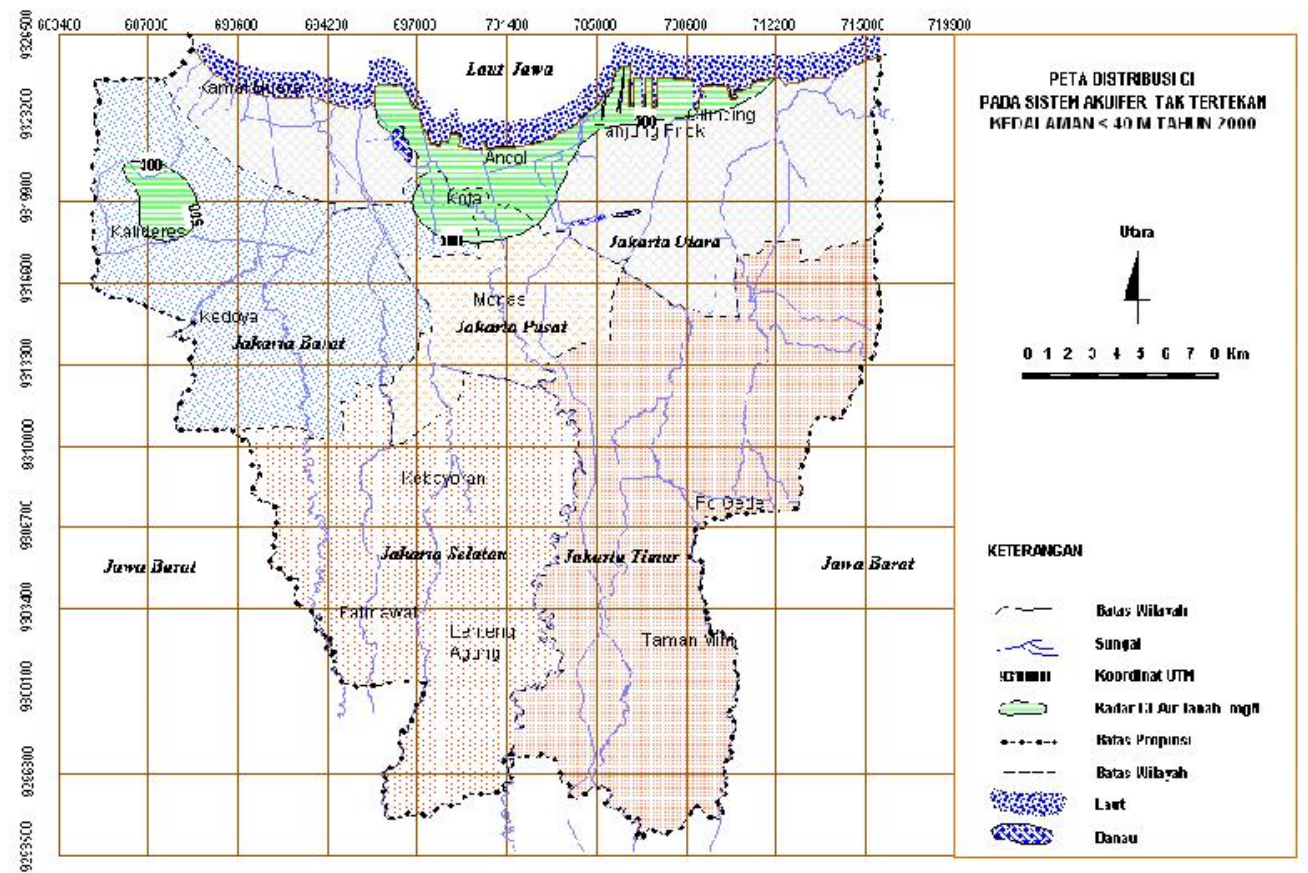

Gambar 1 : Peta Distribusi Cl Pada Sistem Akuifer Tak Tertekan Tahun 2000

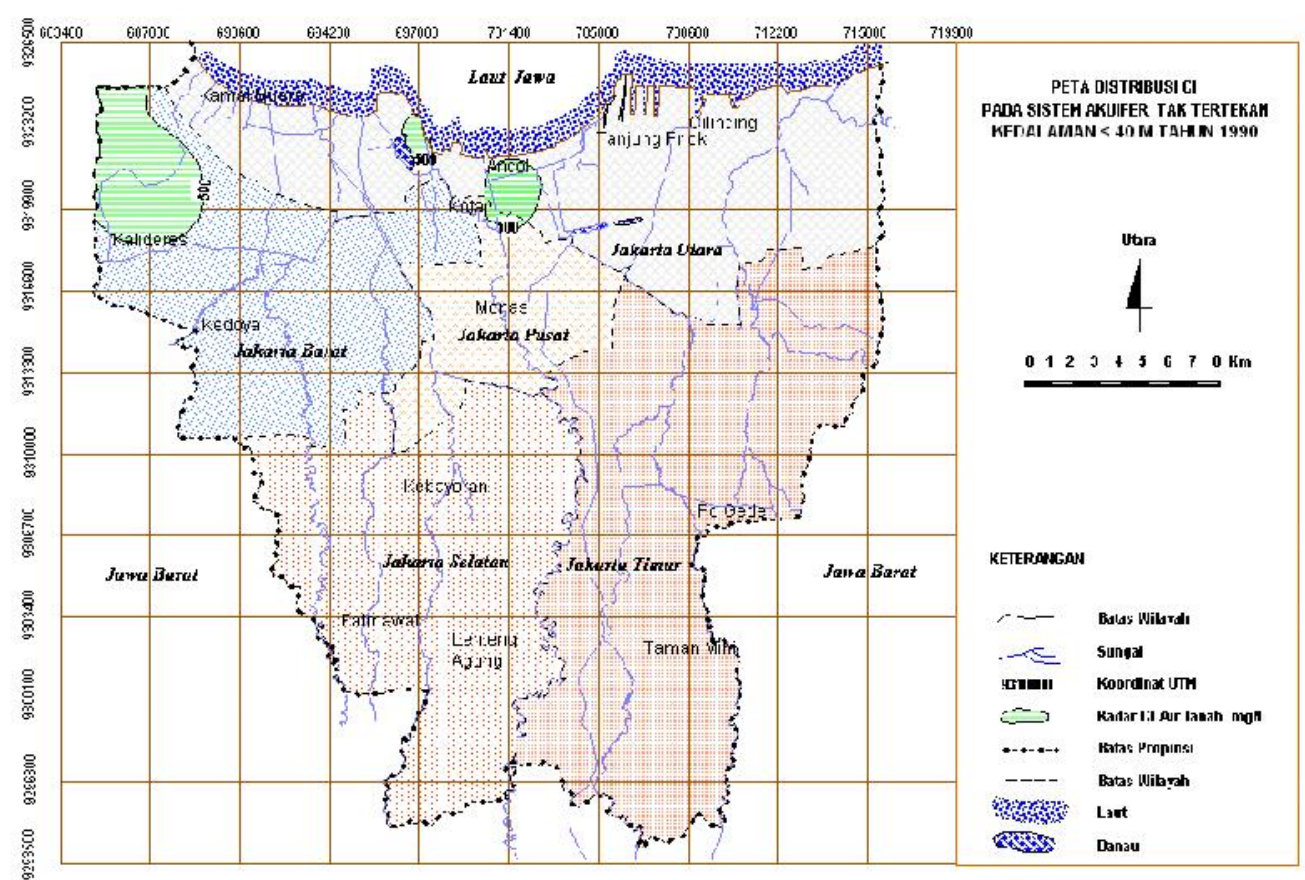

Gambar 2: Peta Distribusi Cl Pada Sistem Akuifer Tak Tertekan Tahun 1990 


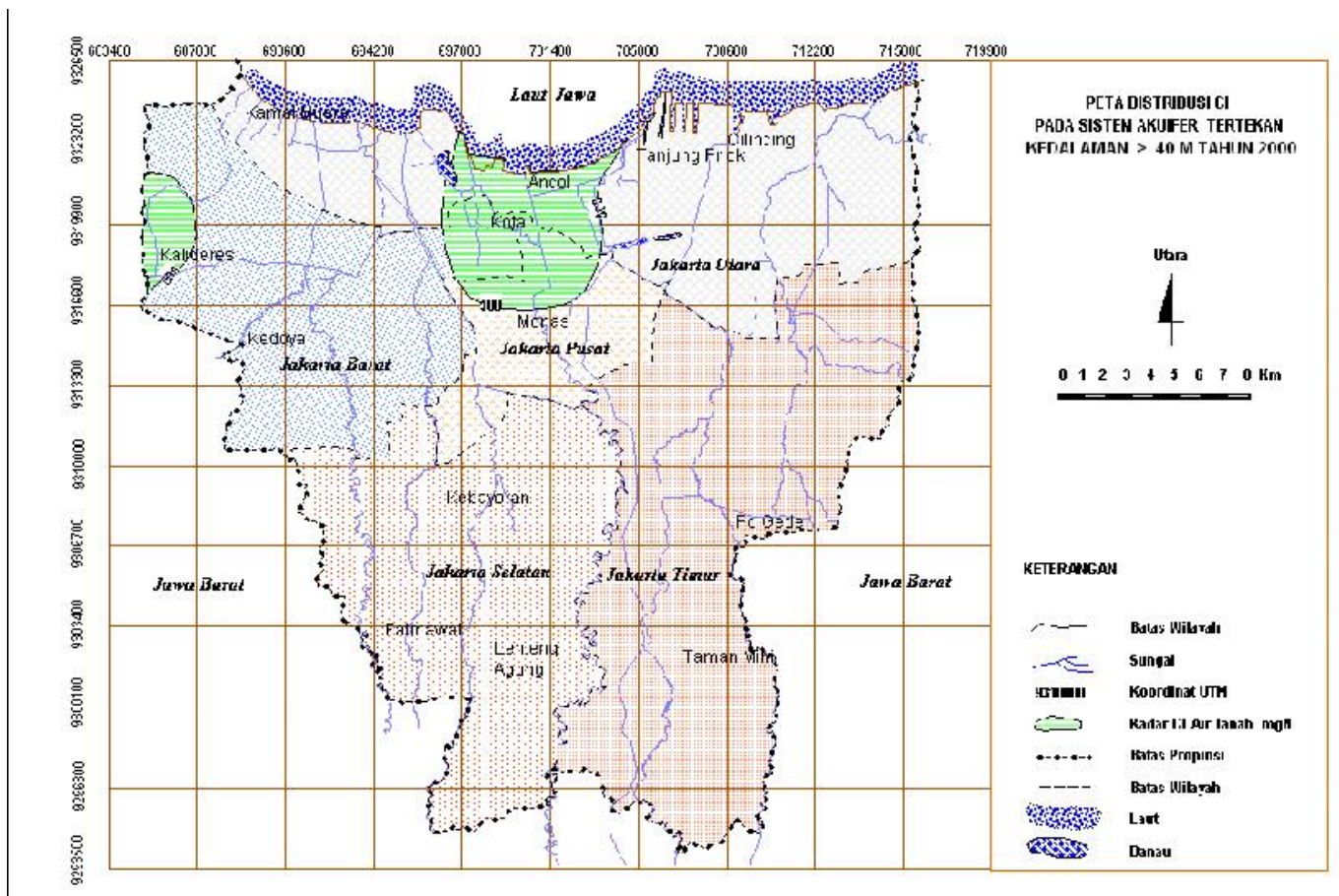

Gambar 3 : Peta Distribusi Cl Pada Sistem Akuifer Tertekan Tahun 2000

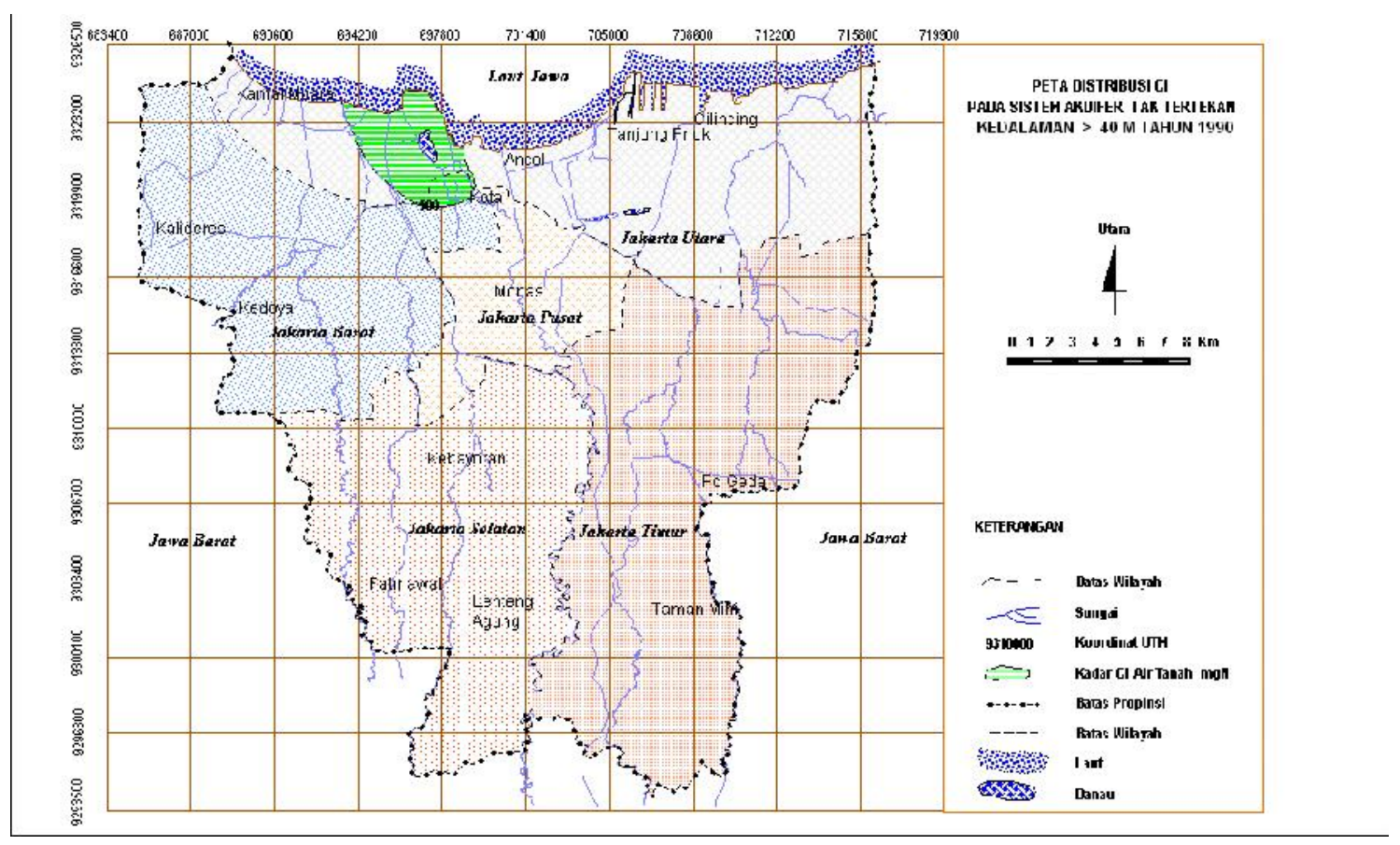

Gambar 4 : Peta Distribusi Cl Pada Sistem Akuifer Tak Tertekan Tahun 1990 


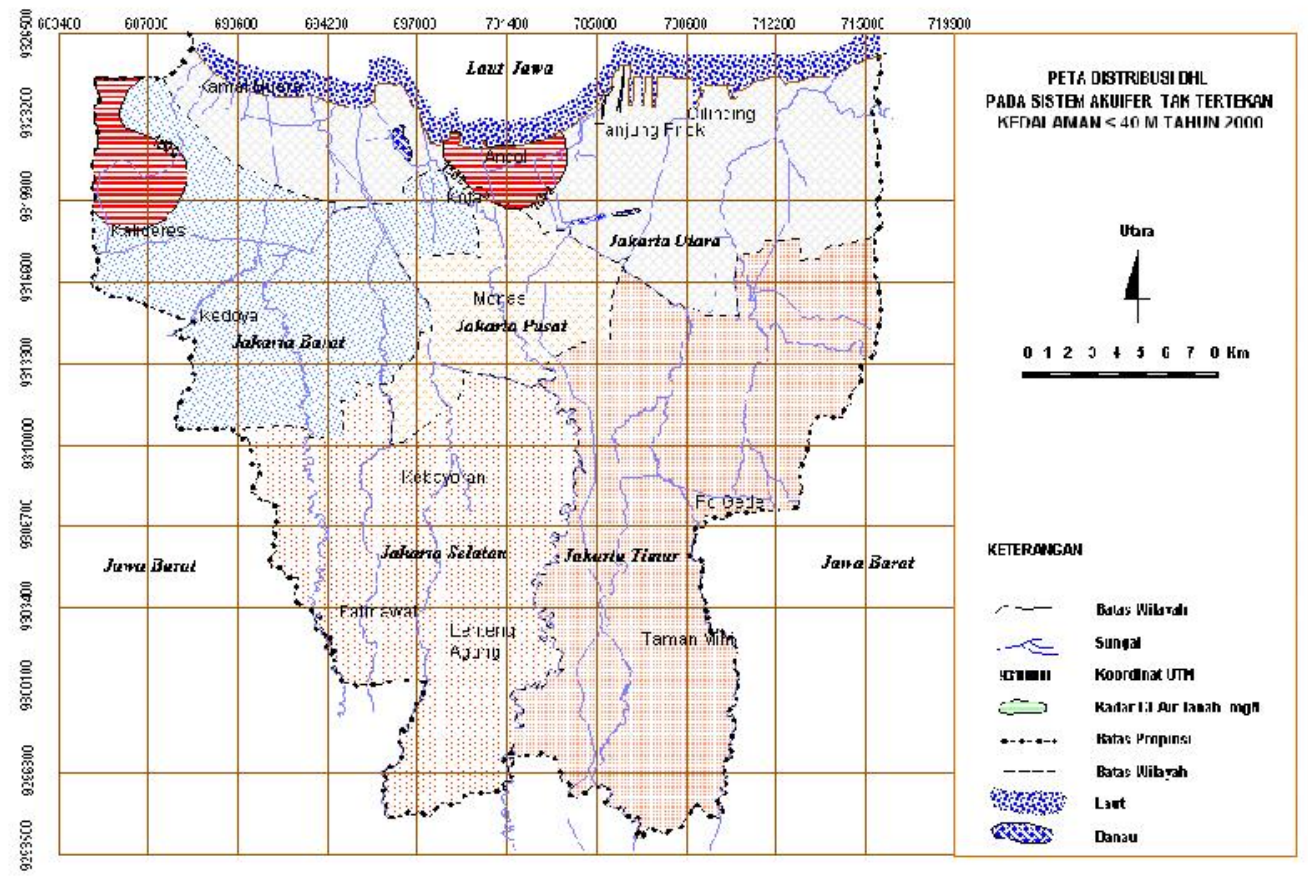

Gambar 5 : Peta Distribusi Dhl Pada Sistem Akuifer Tak Tertekan Tahun 2000

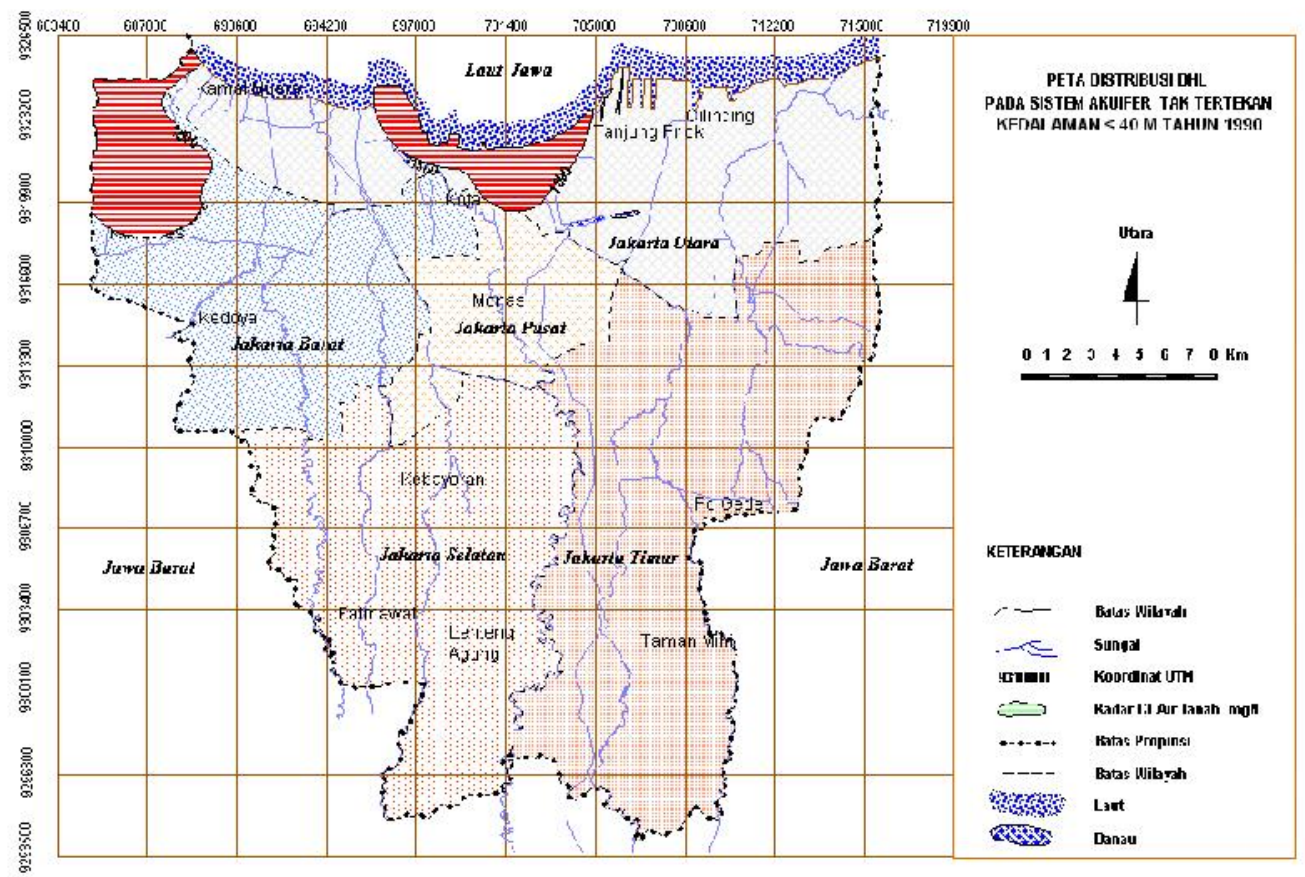

Gambar 6 : Peta Distribusi Dhl Pada Sistem Akuifer Tak Tertekan Tahun 1990 


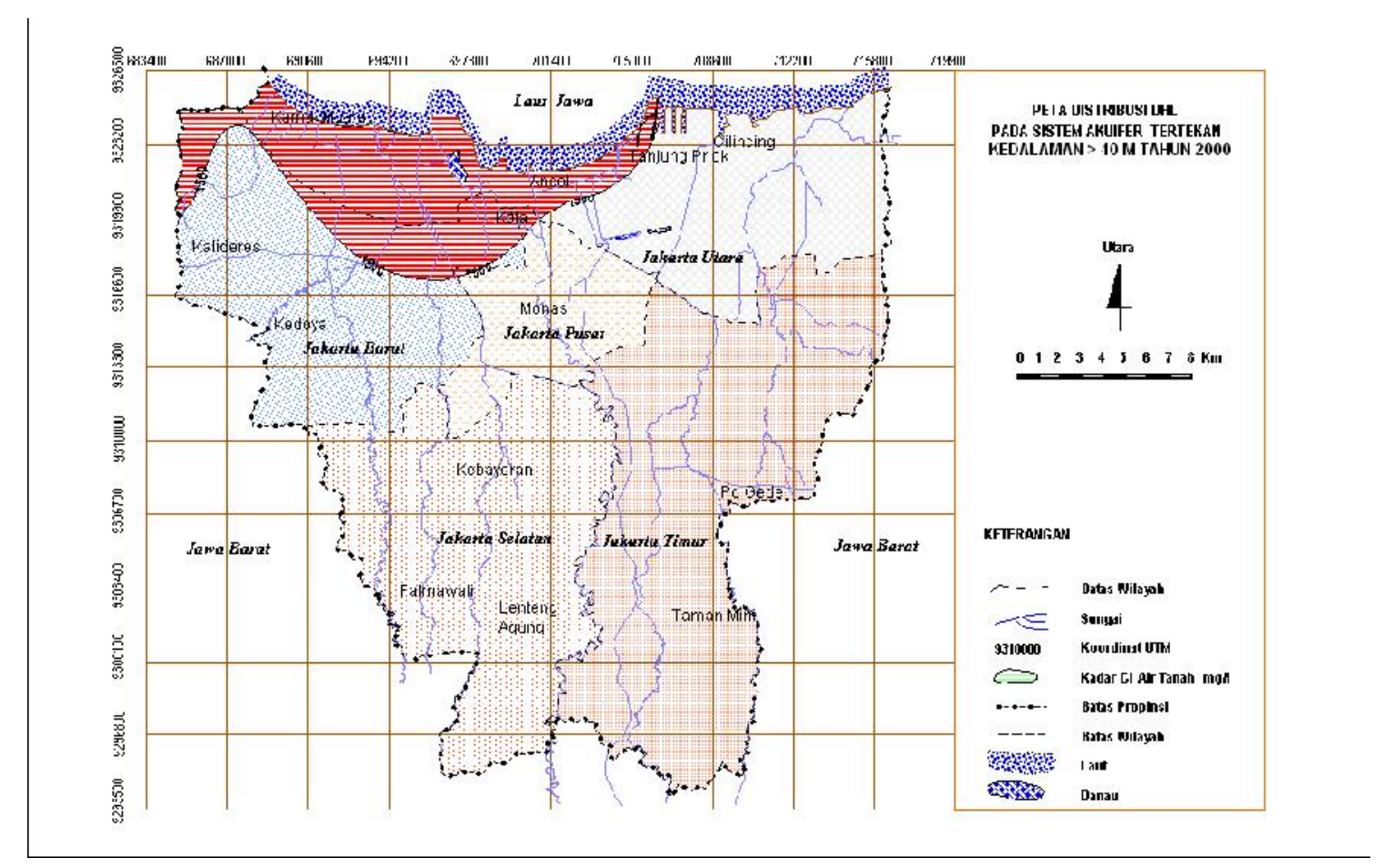

Gambar 7: Peta Distribusi Dhl Pada Sistem Akuifer Tertekan Tahun 2000

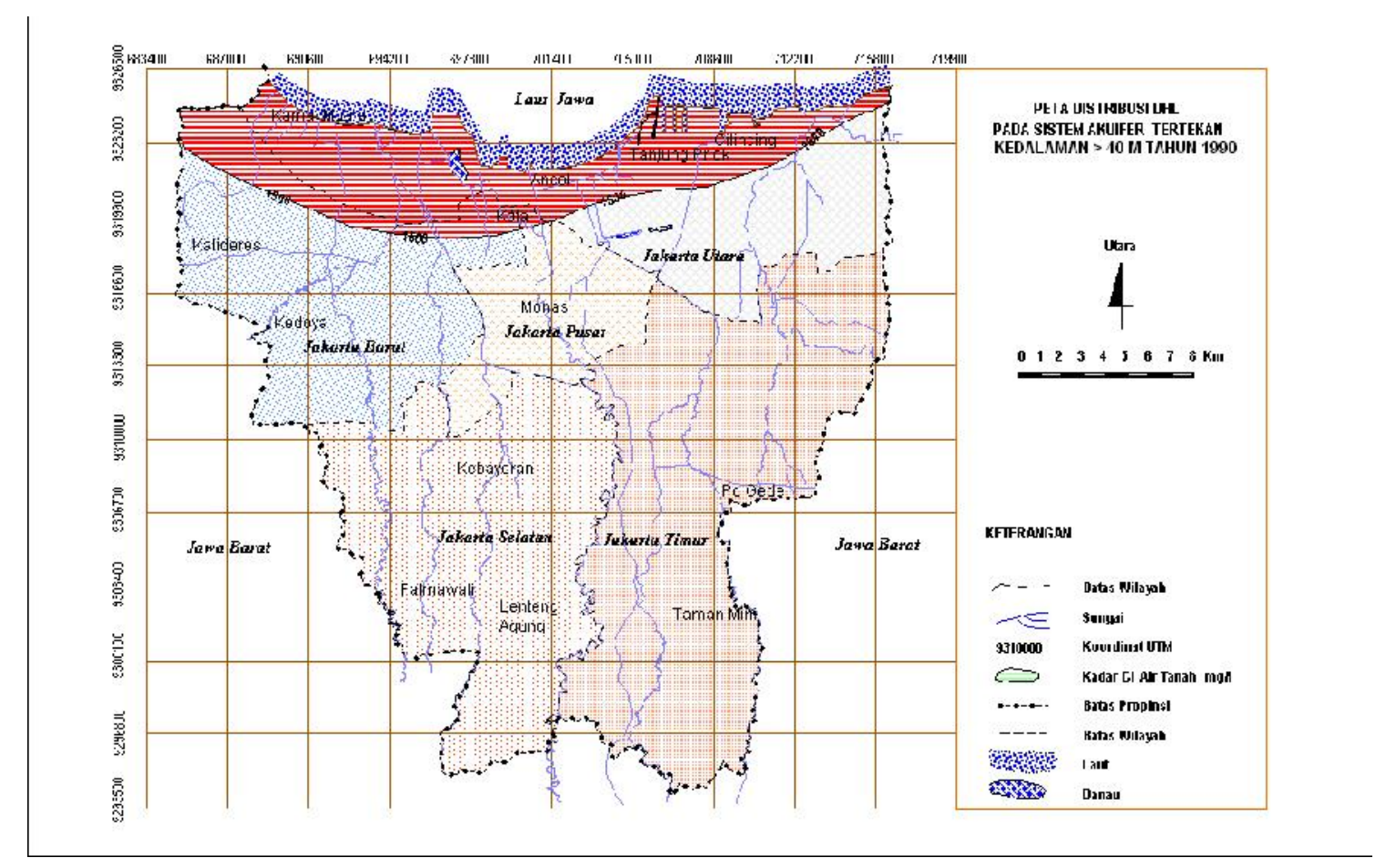

Gambar 8 : Peta Distribusi Dhl Pada Sistem Akuifer Tertekan Tahun 1990 